\title{
Investigating the Availability and Use of ICT Among Secondary School Students Learning During Covid-19 Pandemic Outbreak in Benin City, Edo State, Nigeria
}

\author{
Oboh Stephen O. \\ Benson Idahosa University, Department of Education, Faculty of Arts \& Education, Benin City, Nigeria \\ Ighiwiyisi Blessing O. \\ Benson Idahosa University, Department of Education, Faculty of Arts \& Education, Benin City, Nigeria \\ Oboh Omonyemen J. \\ Department of Pharmaceutical Microbiology, College of Pharmacy, Igbinedion University Okada Nigeria
}

\begin{abstract}
The study investigated the availability and use of ICT among secondary school students learning during Covid19 pandemic Outbreak in Benin City, Edo State, Nigeria. One of the specific purposes was to find out the availability and use of ICT among secondary school students learning during Covid-19 Pandemic outbreak. A descriptive survey research design was employed for the study. The sample was 100 which comprised 28 male and 72 female senior secondary school students (SS1-SS3). A five-point Likert scale questionnaire was structured and used as the instruments for data collection. The instruments were designed for the study, for both male and female secondary school students. The reliability coefficient was 0.75 Cronbach alpha respectively. In all, three research questions were answered using mean and Standard Deviations. The analysis also revealed that most secondary school students in Nigeria don't often utilized online teaching and learning process method, thus, they occasionally utilized online teaching and learning process such as WhatsApp, SMS message, radio, television, e-mails, internet as medium of learning. Finally, the availability and use of ICT e-learning for secondary school students in developing countries, especially Nigeria is rated very poor method of assessment and is ineffective, but also observed that other assessment methods are not effectively utilized for the teaching and learning processes.
\end{abstract}

Keyword: Covid-19 pandemic, ICT, e-learning methods, secondary school students, online teaching and learning process.

DOI: $10.7176 / \mathrm{JEP} / 11-16-10$

Publication date:June 30th 2020

\section{Introduction}

Education is a process of teaching and learning whose primary purpose is to develop individuals' knowledge, skills and behaviour (Burke, Lawrence, El-Sayed, \& Apple, 2009). As put by UNESCO (2006), nations have a quest to provide learning environments that are economically, socially, culturally and physically accessible for all children. It is, therefore, for this quest that countries keep adapting and updating their basic education policies. People can similarly be educated through online reading of e-books, reading books, excursion, exploring their environment or even by attending classes (Peters, 2010). Furthermore, processes in education are viewed as tasks related to achievement; that is to refer to what people can consequently achieve in terms of production at individual, national and international levels (UNESCO, 2007). Thus, School closures due to coronavirus (COVID-19) are affecting learners worldwide. By the end of March 2020, over 180 countries had closed down their schools, affecting $87.4 \%$ of learners (over 1.5 billion students,). Governments are taking action to support learners to continue their education remotely. Some are using technology, but they face a number of challenges as they also deal with countrywide healthcare emergencies and likely economic recession. We know that school closures due to health crises such as Coronavirus, Ebola outbreaks impact learners. They lead to more school dropouts, leave learners at a higher risk of abuse, loss of confidence and self-esteem, and decline in quality teaching and learning process.

In Nigeria, school opportunity is correlated to income level, and public schools differ from private schools in the populations they serve. While private schools serve learners from higher socio-economic backgrounds who are willing and able to pay more to access the better resources offered by private schools, public schools which are usually free, comprise students from lower socio-economic households and lowincome areas. In instances where distance learning opportunities are available, uptake will be low from the students in the public school's category, as a result of poor infrastructure such as lack of electricity, or poor/no internet connectivity, etc.

Opportunities to learn within the homes are also limited, given that a parent's ability to provide education 
support to their children will be shaped by their own level of educational attainment, general literacy level, and other commitments. Given the significant relationship between educational attainment and income level, and the correlation between parental income level and school choice, we can infer that the literacy level of parents in public schools in Nigeria might be lower than their private school counterparts. In instances where the parents are educated, investing the time to train their children during this time might be a luxury. For Nigeria, the reality is simple - while the school closures are necessary to curtail the spread of the COVID19 virus, until the ban on movement is lifted and schools are reopened, majority of students will not be learning. A longer-term impact of these school closures would be deepened educational inequality. While some international development partners (UNESCO, for example) have put together and provided access to ICT-based resources to foster learning, uptake will depend largely on the level and quality of digital and internet access, and language accessibility (as most programs are available in English or other non-native Nigerian languages).

According to the Digital 2020 Global Overview Report published in January 2020, about 60 percent of Nigerians are not connected to the internet. The statistics for mobile phones, which could also be used as a learning medium, are more hopeful. According to the report, around 169.2 million people - 83 percent of Nigerians have access to mobile phone connections; however, of these, 50 percent - around 84.5 million people, reside in urban areas. For the population with access, the proportion would be skewed towards high socioeconomic households and urban households; an overwhelming majority of whom are private school students who already have a learning advantage over their public school peers. For children from poorer backgrounds who tend to have less access to internet connectivity, computers, and other devices, and reside in rural areas where local languages take dominance over English, ICT-learning uptake will be limited. The inequity in access to ICT-based learning has the adverse effect of further intensifying the existing disparities in learning outcomes along socio-economic lines, and the urban-rural divide. Given that the school closures are currently indefinite; these students would continue to fall further behind. For students with learning disabilities, and those living in fragile and conflict-affected regions, the outlook is even more bleak.

By implication, this raises a major challenge around educational inequality - given the technological landscape and income driven digital-divide, how do we harness available technology to support already marginalized students during these closures? For Nigeria, the reality is simple - while the school closures are necessary to curtail the spread of the COVID19 virus, until the ban on movement is lifted and schools are reopened, majority of students will not be learning. We provide evidence from the research and examples to inform policy and programming decisions. If this is unaddressed, the gap in education quality, and inadvertently socio-economic equality could become more extreme as a result of the school closures.

\section{Statement of the Problem}

Truly, consequent upon that the Covid-19 pandemic is and remain a major problem experienced around the world, the challenges of Covid-19 pandemic has resulted to the closure of all schools and institutions of learning in Nigeria, the Covid-19 pandemic is now the main thrust at all levels of governance and the society at large. Therefore, the effect of the Covid-19 pandemic on the Nigerian Education and how the availability and use of ICT influences teaching and learning, and the extent to which the availability and use of ICT impact teaching and learning, thus, the position and the availability and use of ICT to improve the teaching and learning, and the classroom conventional learning is seriously affected due to the pandemic.

Above all, the premium placed on e-learning as a palliative due to the Covid-19 pandemic outbreak has devalued the conventional classroom learning system which foster learning interaction between teachers and students in the teaching and learning process within the classroom and beyond. A close observation shows that seriousness attached to e-learning at this critical period of Covid-19 pandemic seems to have affected the conventional method of teaching and learning. This therefore, should be a concern to Stakeholders in Education. Hence, the research seeks to investigates the effect of Covid-19 on the influence of students' use of ICT during teaching and learning, and the impact of ICT on teaching and learning, and how it ICT improve teaching and learning, therefore, Nigerian students especially with research focus on the online teaching and learning process.

\section{Purpose of the Study}

The purpose of this research was to investigate the availability and use of ICT among secondary school students learning during the Covid-19 Pandemic in Benin City, Edo State, Nigeria.

The research specifically sought to:

1. investigate the extent to which the availability and use of ICT influences the learning of secondary school students during the Covid-19 Pandemic in Benin City, Edo State, Nigeria.

2. determine the extent to which the availability and use of ICT impact the learning of secondary school students during the Covid-19 Pandemic in Benin City, Edo State, Nigeria.

3. determine the extent to which the availability and use of ICT improve the learning of secondary students during the Covid-19 Pandemic in Benin City, Edo State, Nigeria. 


\section{Research Questions}

The following questions were raised to guide the research:

1. to what extent does the availability and use of ICT influences the learning of secondary school students during the Covid-19 Pandemic in Benin City, Edo State, Nigeria?

2. to what extent does the availability and use of ICT impact the learning of secondary school students during the Covid-19 Pandemic in Benin City, Edo State, Nigeria?

3. to what extent does the availability and use of ICT improve the learning of secondary school students during the Covid-19 Pandemic in Benin City, Edo State, Nigeria?

\section{Methodology}

A descriptive survey research design was used in the study. This design was primarily a non-experimental quantitative design in which questionnaire was administered on sample to describe their attitudes, opinions, experiences, or characteristics. The participants comprised 28 secondary school student's boys and 72 girls, giving a sample size of 100. The instrument for data collection was a self-constructed questionnaire, titled:

"Investigating the availability and use of ICT among secondary school students learning during Covid-19 Pandemic in Benin City, Edo State, Nigeria (IAUILCN)". The instrument was a 5-point Likert type, which ranged from 4 (Strongly Agree) to 3 (Agree), 0 (Undecided) to 2 (Strongly Disagree), and 1(Disagree) respectively. The instruments' reliability were Cronbach alpha coefficient of 0.75 for students.

6. Results

Analysis of Demographic Data Table 1: Respondents of the study by Age

\begin{tabular}{|c|c|c|}
\hline Age range & frequency & percent \\
\hline 10-15 & 42 & $42 \%$ \\
\hline $15-20$ & 32 & $32 \%$ \\
\hline $20-25$ & 26 & $26 \%$ \\
\hline Total & 100 & $100 \%$ \\
\hline
\end{tabular}

Table 1: shows frequency and percentage of respondents by age range. It revealed that $42 \%$ were within the age range of $10-15,32 \%$ were within the age range of $15-20$ while $26 \%$ were within $20-25$ years old. Thus, majority of respondents fall within the age 10-15.

Table2: Distribution of Respondents by Gender

\begin{tabular}{lcc}
\hline Gender & frequency & percent \\
\hline Male & & \\
Female & 28 & $28 \%$ \\
Total & 72 & $72 \%$ \\
\end{tabular}

Table2: showed that $28 \%$ respondents representing male while $72 \%$ were female. This implies that both gender participated in the study.

Table3: Distribution of Respondents by Class

\begin{tabular}{lcc}
\hline Class & frequency & percent \\
\hline SS 1 & & $34 \%$ \\
SS 2 & 34 & $18 \%$ \\
SS 3 & 18 & $48 \%$ \\
Total & 48 & $100 \%$
\end{tabular}

Table3: Distribution by student compliant and non-compliant to Covid-19 NCDC precaution

\begin{tabular}{lcc}
\hline Categories & frequency & percent \\
\hline Compliant & & $74 \%$ \\
Non-compliant & 74 & $26 \%$ \\
Total & 26 & $100 \%$ \\
\end{tabular}


Table3: also revealed that out of the total respondents of 100 who participated in the study, 74 respondents representing 74\% reported that they are and currently complaining to NCDC precaution while 26 respondents representing $26 \%$ were found as non-compliant to NCDC precaution. This means that there was $18.5 \%$ number of students who reported to be complaining to e-learning.

\subsection{Research Question 1:}

to what extent does the availability and use of ICT influences the learning of secondary school students during the Covid-19 Pandemic in Benin City, Edo State, Nigeria?

The analysis of data in respect of research question 1 is shown in Table 1:

Tof the Availability and use of ICT influences learning of Secondary School Students during the Covid-19 Pandemic in Benin City, Edo State, Nigeria.

\begin{tabular}{lllll}
\hline S/N & Item Statements & Mean frequency & SD & Remarks \\
\hline 1. & I have internet facilities at home & 2.93 & 1.33526 & Strongly Agree \\
2. & I am connected to internet at home & 2.7 & 1.40346 & Strongly Agree \\
3. & I often use the internet during e-learning class & 1.84 & 1.40504 & Disagree \\
4. & I found e-learning to be fun & 2.47 & 1.43164 & Disagree \\
5. & Which do you prefer learning from home or in school & 2.04 & 1.58860 & Strongly Agree \\
6. & I am anxious about my certificate examination & 2.32 & 1.58197 & Disagree \\
7. & I really wish to be back to school & 2.52 & 1.60479 & Strongly Agree
\end{tabular}

The data in Table 1 showed that 3 items, with serial number 1, 2, and 7 had the mean scores that ranged from 2.7 to 2.93, and the corresponding Standard Deviations values ranged from 1.40364 to 1.60478 . The mean scores imply that secondary school students really want to be back to school to continue their studies despite the Covid-19 pandemic outbreak. The corresponding Standard Deviations values imply that student's response were very close. The table also showed that 4 items, with serial number 3, 4, 5, and 6 had the means scores that ranged from 1.84 to 2.04, and the corresponding Standard Deviation ranged from 1.40504 to 1.588860 response towards school resumption was weak. The mean scores imply that students were interested in returning to school, and the feedbacks were rarely done with the intention for school to reopen so as to continue with normal learning within the classroom.

\subsection{Research Question 2:}

to what extent does the availability and use of ICT impact the learning of secondary school students during the Covid-19 Pandemic in Benin City, Edo State, Nigeria?

The analysis of data in respect of Research Question 2 is shown in Table 2:

Table 2: The Mean Rating of the Availability and use of ICT impact Learning of Secondary School Students during the Covid-19 Pandemic compare to classroom conventional learning in Benin City, Edo State, Nigeria.

\begin{tabular}{|c|c|c|c|}
\hline Item Statements & Mean impact & $S D$ & Remarks \\
\hline 1.I prefer taking my lectures online & $2.13 \quad 1$ & 1.20315 & Disagree \\
\hline 2.Why learning from home I am easily distracted & 2.47 & 1.50726 & Disagree \\
\hline $\begin{array}{l}\text { 3.Not seeing my teacher during learning have negative } \\
\text { impact on learning }\end{array}$ & 2.70 & 1.25931 & $\begin{array}{l}\text { Strongly } \\
\text { Agree }\end{array}$ \\
\hline 4. My level of concentration is the same as if I was in classroom & 1.92 & 1.28456 & $\begin{array}{l}\text { Strongly } \\
\text { Disagree }\end{array}$ \\
\hline 5. I understand better learning from home than in the school & 1.610 & 1.31729 & Disagree \\
\hline 6. The learning environment is conducive at home & 1.96 & 1.23844 & Disagree \\
\hline 7. I easily sleep off while learning at home & 2.5 & 1.42489 & Agree \\
\hline 8. I prefer to be around my classmate while learning & 2.56 & 1.29739 & Agree \\
\hline $\begin{array}{l}\text { 9. I am very conversant using the laptop in the teaching } \\
\text { and learning process }\end{array}$ & 1.97 & 1.37404 & $\begin{array}{l}\text { Strongly } \\
\text { Disagree }\end{array}$ \\
\hline 10. There is power supply during my online lectures & 2.12 & .37275 & Disagree \\
\hline 11. I have easy access to online materials & 2.43 & .27331 & Disagree \\
\hline 12. Online learning look like you are in the conventional classroom & 1.78 & .25995 & Strongly \\
\hline 13. Lack of access to internet facilities makes e-learning difficulty & 2.72 & 1.36389 & Strongly Agree \\
\hline 14. The inequity in access to ICT-based learning has the adverse effect & 2.05 & 1.59782 & Disagree \\
\hline 15.Access to ICT-based resources foster learning & 2.10 & .42489 & Disagree \\
\hline
\end{tabular}


The data in Table 2 showed that 1 item, which is serial number 1 had the mean score of 2.13 , and a corresponding Standard Deviation value of 1.20315. The mean scores imply that secondary school students don't often use the online method of learning they still prefer conventional classroom learning. The corresponding Standard Deviations values imply that secondary school student's responses as against elearning were not very close. The table also showed that 11 items, with serial 2, 3, 4, 5, 6, 7, 8, 10,11, 12, 13, 14, and 15 had the mean scores that ranged from 1.92 to 1.610 , and the corresponding Standard Deviations values ranged from 1.96 to 1.97. The mean scores imply that students occasionally utilized online learning method, while the corresponding Standard Deviations values imply that students' responses were not very close.

\subsection{Research Question 3:}

to what extent does the availability and use of ICT to improve the learning of secondary school students during the Covid-19 Pandemic in Benin City, Edo State, Nigeria?

The analysis data of in respect to Research Question 3 is shown in Table 3:

Table 3: The Mean Rating of the Availability and use ICT to improve the learning of Secondary School Students during the Covid-19 Pandemic in Benin City, Edo State, Nigeria.

\begin{tabular}{|c|c|c|c|c|}
\hline \multirow{2}{*}{$\begin{array}{l}S / N \\
1 . \\
\text { and il }\end{array}$} & \multirow{2}{*}{$\begin{array}{l}\text { Item Statements } \\
\text { Would the availability of ICT bridge the gap } \\
\text { rove on students' learning }\end{array}$} & Mean effect & \multicolumn{2}{|c|}{ SD Remarks } \\
\hline & & 2.04 & 1.61383 & Disagree \\
\hline $\begin{array}{l}2 . \\
\text { stude }\end{array}$ & $\begin{array}{l}\text { Would the use of ICT help during learning to improve } \\
\text { learning interest }\end{array}$ & 2.68 & 1.40619 & $\begin{array}{l}\text { Strongly } \\
\text { Agree }\end{array}$ \\
\hline $\begin{array}{l}3 . \\
\text { stude }\end{array}$ & $\begin{array}{l}\text { Would ICT platform use to stimulating or arousing } \\
\text { interest to learning }\end{array}$ & 1.93 & 1.52590 & Disagree \\
\hline $\begin{array}{l}4 . \\
\text { emoti }\end{array}$ & $\begin{array}{l}\text { Would the closure of schools have psychological } \\
\text { al and intellectual effect on students }\end{array}$ & 2.59 & 1.42910 & $\begin{array}{l}\text { Strongly } \\
\text { Agree }\end{array}$ \\
\hline $\begin{array}{l}5 . \\
\text { a bala } \\
\text { calen }\end{array}$ & $\begin{array}{l}\text { Would the availability and use of ICT help to create } \\
\text { e in the school }\end{array}$ & 1.59 & 1.41489 & Disagree \\
\hline
\end{tabular}

The data presented in Table 3 showed that 1 item, which is serial number 1 had a mean score of 2.04, and the corresponding Standard Deviation value of 1.61383. The mean scores imply that students rated answers to the questions on Covid-19 pandemic will interrupt school calendar. The corresponding Standard

Deviations values imply that student's responses were not very close. The table also showed that 4 item, with the serial number 2, 3, and 5 had the mean scores that ranged from 1.95 to 2.68, the corresponding Standard Deviations values ranged from 1.40619 to 1.52590 . The mean scores imply that students' responses prove abortive, and the corresponding Standard Deviations values imply that students' responses were not very close.

\section{Discussion of Results}

The findings of this study are supported by numerous researches which revealed limited extent in e-learning implementation of formative assessment methods in knowledge, skills and behaviour development, which consequently hinders students' academic achievements or learning outcomes (Bell, Steinberg, Wiliam, \& Wylie, 2008; Randel, Beesley, Apthorp, Clark, Wang, Cicchinelli \& Williams, 2011). The results of this study is equally consistent with emerging stream of research which found that attempts to promote elearning among secondary school students in Nigeria have been frequently unsuccessful (Carless, 2005; De Lisle, 2015; Hume \& Coll, 2009; James \& McCormick, 2009; Marshall \& Drummond, 2006; Schneider \& Randel, 2010; Wylie \& Lyon, 2015), to the extent that poor students' achievement was obtained (Bell, et al., 2008; Jönsson, Lundahl, \& Holmgren, 2015).

Although, there are several issues that make the implementation of e-learning methods for the effective teaching and learning processes difficult for learning during the Covid-19 pandemic (Andersson \& Palm, 2018). Firstly, e-learning practice is complex (Vingsle, 2014), and using online information to plan subsequent instruction is difficult (Heritage, Kim, Vendlinski, \& Herman, 2009; Schneider \& Meyer, 2012). Secondly, external factors, such as, availability, accessibility to internet during the online learning, constant power failure, e.t.c. (Darling-Hammond \& McCloskey, 2008; Klenowski, 2011) and the focus on examination or online assessment (Bennett, 2011; Brown, Kennedy, Fok, Chan \& Yu, 2009; Wiliam, 2006) hinder the implementation of e-learning despite the Covid-19 pandemic outbreak. Misconceptions of meaning and aims of e-learning in developing countries, conceptions of its value and time to implement it, and beliefs about teaching and learning has also hinder integration of e-learning into classroom teaching and learning process (DeLuca, Luu, Sun \& Klinger, 2012). The implication is that e-learning learning for learners who do not see or have access to 
computers, laptop, as a tool to promote effective teaching and learning processes cannot utilize the teaching and learning methods online. Hence, those teachers who poorly practiced online assessment are held responsible for the low quality of education.

\section{Conclusions}

Based on the findings, the authors of this research study concludes that the ineffective implementation of elearning methods within the processes of teaching and learning during the Covid-19 Pandemic specifically for Nigeria secondary school students appears to be responsible for poor students' academic achievements in the programme. Despite this concluding remark, the authors still recommend that the findings of the study will propel more teachers to researches online that will enable students to develop interest in the online teaching and learning process (assessment for learning researches) in other academic fields in order to determine whether the results of this study will be consistent.

\section{Practical Implications}

Research on availability and use of ICT e-learning methods in the teaching and learning process in general is lacking, especially in Nigeria. The results of this study, therefore, have serious implications for educational stakeholders and researchers regarding the influence of e-learning assessment in the teaching and learning of Education in Nigeria. Firstly, the study found out that secondary school students are anxiously hoping when the Covid-19 pandemic will be over in order for school to resume, so as to enable normal conventional classroom teaching and learning process continue; that is reliable while students' are finding e-learning as a strange method in the Nigeria educational system; and that feedback is rarely done with intention to effect correction through interaction. The study also found that e-learning often use question and answer method and occasionally utilized other assessment methods. Finally, the study found out that secondary school students and teachers rated question and answer as online methods as not be effective but observed that other assessment methods are not quite effective either.

The poor nature of the instructional processes in online Education cannot control or neither regulates students' learning. Thus, it would be very helpful for all major stakeholders of Education to jointly implement a high degree of assessment literacy programme among practitioners and those that are involved in the Education System, which is highly crucial for attaining e-learning outcomes. Similarly, the educational stakeholders such as non-governmental organizations, employers and parents should endeavour to collaborate with Educational administrators to ensure the optimization of instructional resources to improve online practice, interactive feedback, and collaboration among teachers and students. These recommendations would help to strengthen the relationship between e-learning assessment and effective teaching and learning processes in our Education. By and large, the implementation of online assessment literacy programme and optimization of instructional resources through strategic collaboration would assist in fostering the utilization of online assessment methods on the effective teaching and learning processes in Education in the Nigerian secondary school and tertiary institutions.

\section{Recommendations}

In line with the findings, discussion of results, practical implications and conclusions of this study the following recommendations were made by the researcher:

1. Government at all levels should endeavour that the availability and use of e-learning as an educational palliative serve the learners in rural and urban area, and develop individuals' knowledge, skills and behaviour in the society in other not to create inequality in the online learning process, thus, educational palliatives provided by the government should foster and meet immediate needs of the learners affected by the Covid-19 pandemic outbreak. Therefore, government should give a periodic in-service training to teachers in senior secondary schools on the different ICT strategies that will serve learners in urban and rural areas in the online teaching and learning process.

2. Stakeholders should have a unique opportunity to explore how this emerging reality could usher in a new educational architecture that tackles two of the nations most urgent pre-pandemic education crisis. Access (the country has the highest out of school children in the world) and quality (as majority of the children in school are not learning). Therefore, school administrators should devise means of motivating teachers and students towards proper using different procedures of making elearning attractive to secondary school students from developing countries and further boosting teachers and students' knowledge of e-learning in the teaching and learning process either online or the conventional classroom learning.

3. More effort should be made by the government and stakeholders of education to train and retrain teachers in E-communication in the teaching and learning process. It gives room for a wider range of teaching activities. Individuals students will have the opportunity to relate with teachers online as it is 
in developed countries. Thus, organizing workshops, seminars and conferences for teachers and students to retain their knowledge on the advent of online communication between teachers and students at this critical period of Covid-19 pandemic outbreak.

4. Government and NGO's should establish more e-learning centers in every field of organizations in government custody. There should be at least more e-learning school from nursery to tertiary institutions depending on the population strength. It creates an atmosphere for early introduction of children to e-learning practice which is intended to foster quality education.

\section{References}

Anderson, C., \& Palm, T. (2018). Reasons for teachers' successful development of a formative assessment practice through professional development - a motivation perspective, Assessment in Education: Principles, Policy \& Practice, 1-22.

Bell, C., Steinberg, J., William, D., \& Wylie, C. (2008). Formative assessment and teacher achievement: Two years of implementation of the Keeping Learning on Track Programme. Paper presented at the annual meeting of the National Council on Measurement in Education, New York, NY.

Burke, K., Lawrence, B., El-Sayed, M., \& Apple, D. (2009). Process Education: Past, Present, and Future. International Journal of Process Education, 35-41.

Bennett, R. E. (2011). Formative assessment: A critical review. Assessment in Education: Principles, Policy \& Practice, 18 (1), 5-25. doi:10.1080/0969594X.2010.513678

Black, P., Harrison, C., Lee, C., Marshall, B., \& William, D. (2004). Working inside the black box: Assessment for learning in the classroom. Phi Delta Kappan, 86 (1), 8-21.

Brown, G. T. L., Kennedy, K. J., Fok, P. K., Chan, J. K. S., \& Yu, W. M. (2009). Assessment for student improvement:

Understanding Hong Kong teachers' conceptions and practices of assessment. Assessment in Education: Principles, Policy \& Practice, 16 (3), 347-363.

Carless, D. (2005). Prospects for the implementation of assessment for learning. Assessment in Education Principles Policy and Practice, 12 (1), 39-54. doi: 10.1080/0969594042000333904

De Lisle, J. (2015). The promise and reality of formative assessment practice in a continuous assessment scheme: The case of Trinidad and Tobago. Assessment in Education: Principles, Policy \& Practice, 22 (1), 79-103. doi: 10.1080/0969594x.2014.944086

Darling-Hammond, L., \& McCloskey, L. (2008). Assessment for learning around the world what would it mean to be internationally competitive? The Phi Delta Kappan, 90 (4), 263-272.

DeLuca, C., Luu, K., Sun, Y., \& Klinger, D. A. (2012). Assessment for learning in the classroom: Barriers to implementation and possibilities for teacher professional learning. Assessment Matters, 4, 5-29.

Hume, A., \& Coll, R. (2009). Assessment of learning, for learning, and as learning: New Zealand case studies. Assessment in Education: Principles, Policy \& Practice, 16 (3), 269-290. doi: 10.1080/09695940903319661

James, M., \& McCormick, R. (2009). Teachers learning how to learn. Teaching and Teacher Education: An International Journal of Research and Studies, 25 (7), 973-982. DOI: 10.1016/j.tate.2009.02.023 Jarvis,

Marshall, B., \& Drummond, M. J. (2006). How teachers engage with assessment for learning: Lessons from the classroom. Research Papers in Education, 21 (2), 133-149. doi: 10.1080/02671520600615638 Oboh, S, O. \& Oboh, O, J. (2020). An Enquiry into the Covid-19 crisis on the Nigeria Education System:

Unpublished Paper.

Oboh, S, O. \& Oboh, O, J. (2020). Covid-19 and its Effect on Secondary School Students Learning in Benin City, Edo State, Nigeria. Unpublished Paper.

Oboh, S, O. \& Oboh, O, J. (2020). Covis-19 Pandemic Outbreak and Government Policy on Educational Infrastructure in Nigeria. Unpublished Paper.

Oboh, S, O. \& Oboh, O, J. (2020). Covid-19 Impending Deepen Crisis and Higher Education in Nigeria. Unpublished Paper.

Peters, S. (2010). Literature Review: Transition from Early Childhood Education to Schools. Hamilton: Ministry of Education, New Zealand.

Randel, B., Beesley, A. D., Apthorp, H., Clark, T. F., Wang, X., Cicchinelli, L. F., \& Williams, J. M. (2011). Classroom assessment for student learning: Impact on elementary school mathematics in the central region (NCEE 20114005). Washington, DC: National Center for Education Evaluation and Regional Assistance, Institute of Education Sciences, U.S. Department of Education.

Schneider, M. C., \& Randel, B. (2010). Research on characteristics of effective professional development programs for enhancing educators' skills in formative assessment. In H. L. Andrade \& G. J. Cizek (Eds.), Handbook of formative assessment (251-276). Abingdon: Routledge.

Schneider, M. C., \& Meyer, J. P. (2012). Investigating the efficacy of a professional development program in 
formative classroom assessment in middle school English language arts and mathematics.Journal of MultiDisciplinary Evaluation, 8 (17), 1-24.

Schneider, M. C., \& Randel, B. (2010). Research on characteristics of effective professional development programs for enhancing educators' skills in formative assessment. In H. L. Andrade \& G. J. Cizek (Eds.), Handbook of formative assessment (251-276). Abingdon: Routledge.

Vingsle, C. (2014). Formative assessment: Teacher knowledge and skills to make it happen (Licentiate dissertation). Umeå University, Department of Science and Mathematics Education.

UNESCO(2020) Adverse consequences of school closures. UNESCO.

UNESCO (2020) COVID-19 educational disruption and response. UNESCO. UNESCO Institute of Statistics (2020) UIS Statistics. UNICEF

UNESCO. (2006, February). The Meaning of Education. PRELAC Journal, 1-144.

UNESCO (2006). The meaning of Education for all: PRELAC Journal, Latin American and the Caribbean, OREAL/UNESCO Santiago.

UNESCO (2007). A human right based approach to education for all; UNICEF. New York.

UNESCO (2015). Education for all 2000-2015: Achievement and challenges; EFA Global monitoring report 2015, pp. 75-103, UNESCO. Paris.

Wylie, C., \& Lyon, C. (2015). The fidelity of formative assessment implementation: Issues of breadth and quality. Assessment in Education: Principles, Policy \& Practice, 22 (1), 140-160. doi:10.1080/0969594x.2014.990416 